\section{Łukasz Bergel}

Uniwersytet Śląski w Katowicach

luketauzen@gmail.com

ORCID: 0000-0003-4031-4146

\section{Biblica}

et

Patristica

Thoruniensia

11 (2018) 1:11-33

ISSN (print) 1689-5150

ISSN (online) 2450-7059

\title{
Pieśń Mojżesza i Baranka. Znaczenie muzyki wokalnej, instrumentalnej i tańca $w$ tekście biblijnym na podstawie Ap 15,2-4 - studium egzegetyczno-teologiczne
}

\section{The Song of Moses and of the Lamb. The Meaning of Vocal and Instrumental Music and Dance in the Biblical Text on Basis of Rev 15:2-4 - An Exegetical-Theological Study}

Streszczenie. Muzyka towarzyszy wielu wydarzeniom opisanym w Biblii. Protagoniści wyrażają za jej pomocą radość, dziękczynienie, uwielbienie, a także ból i rozpacz. Jak pokazuje cała historia biblijna, a w szczególności tekst Apokalipsy, jakość i ukierunkowanie muzyki wyraża relację, w jakiej człowiek znajduje się wobec Boga. Poprzez studium synchroniczne oraz egzegezę autor stara się przedstawić wspomnianą zależność muzyki i wiary w Boga, ten sposób odpowiadając na pytanie o znaczenie wzmianek muzycznych w Biblii.

Abstract. Music is a companion to many of the events described in the Bible. The protagonists express their joy, thankfulness, worship, but also pain and despair. The whole biblical narration, especially the text of Revelation, shows that the quality and focus of music is a expression for the relationship between God and man. Through synchronic study and exegesis, the author tries to present the aforementioned dependency of music and faith in God. In this way answering the question about the meaning of musical references in the Bible.

Słowa kluczowe: muzyka w Biblii; znaczenie muzyki w Biblii; Apokalipsa.

Keywords: music in Bible; the meaning of music in Bible; Revelation. 
$\mathrm{K}$ sięgi biblijne powstawały przez wieki. Duch Pański inspirował autorów do spisywania opowiadań o wielkich dziełach Bożych. Wielokrotnie przedstawianym wydarzeniom towarzyszyła muzyka i różne jej przejawy, takie jak śpiew, taniec czy gra instrumentalna. Jakie jest znaczenie tych wzmianek muzycznych w Biblii? Niniejsze studium ma na celu wskazać to znaczenie na podstawie perykopy Ap 15,2-4. Fragment ten można uznać za kulminację wszystkich wydarzeń, którym towarzyszy muzyka. Jest bogaty w symbolikę starotestamentalną, a poprzez swoje bezpośrednie nawiązanie do sceny przejścia przez morze, spina historię zbawienia jakby klamrą. Stąd też stanowi on centralny tekst niniejszych rozważań.

Obecność i znaczenie muzyki w Biblii można uznać za dość nowatorski temat. Wielkie zasługi należą się J. Montagu za jego dzieło Instrumenty muzyczne Biblii, choć skupia się on jedynie na opisie instrumentarium, bez dalszych rozważań teologicznych. J. Ratzinger w swoich dziełach opisuje teologiczne znaczenie muzyki w Biblii ${ }^{1}$. Jest to jednak opis dość ogólny i stanowi podstawę do rozważań liturgicznych. Jednak jeśli chodzi o jej znaczenie w Piśmie Świętym, jest to ciągle niedostatecznie opracowane zagadnienie. Stąd to studium i przedstawienie jednej z wielu możliwych perspektyw.

Pierwsza część tego dzieła zawiera studium synchroniczne. Prezentuje wszystkie te fragmenty Biblii, w których występuje muzyka wokalna, instrumentalna oraz taniec. Służy ona za konieczną podstawę do dalszych rozważań nad tematem. Druga część jest egzegezą Ap 15,2-4 i na podstawie tego tekstu przedstawia możliwe znaczenie wymienionych elementów w narracji i teologii biblijnej. Ten sposób przeprowadzenia studium zapewnia wnikliwe zgłębienie problematyki.

\section{Obecność muzyki w Biblii}

W pierwszej kolejności warto przedstawić wszystkie okoliczności, w których na kartach Biblii można znaleźć jakiekolwiek formy wyrazu muzycznego, żeby nakreślić tło do głębszych rozważań. Prezentacja poszczególnych elementów ułożona jest następująco: najpierw omówiony jest śpiew w Starym i Nowym Testamencie; następnie przedstawiono użycie instrumentów muzycznych według ich rodzaju (strunowe, dęte, perkusyjne); na końcu wskazano te teksty biblijne, które zawierają wzmianki o tańcu.

1 Por. J. Ratzinger, Nowa Pieśń dla Pana; idem, Duch liturgii. 
Pierwszy raz w kanonie Pisma Świętego można spotkać się ze śpiewem² po przejściu Izraelitów przez morze (Wj 15,1-21). Fragment ten jest szczególnie interesujący ze względu na jego podobieństwo z Ap 15,2-4, co jest jednak omawiane w dalszej części. Śpiew towarzyszył Narodowi Wybranemu w wielu podniosłych momentach. Pieśń była obecna podczas ich wędrówki przez pustynię, gdy Bóg dał im wodę (Lb 21,16-18), gdy prowadzili wojny z ludami ją zamieszkującymi (Lb 21,25-30).

W Biblii śpiew bardzo często kojarzy się z walką i zwycięstwem³ ${ }^{3}$ W epoce sędziów po zwycięstwie nad Siserą, wodzem wojsk kananejskich, Debora i Barak śpiewali wielką pieśń na cześć Pana (Sdz 5,1-31). Śpiewano po zwycięstwie Judyty nad Holofernesem (Jdt 15,13-14), po pokonaniu Gorgiasza przez Machabeuszy (1 Mch 4,24), przy oczyszczeniu świątyni ${ }^{4}$ (1 Mch 4,54; 2 Mch 10,7). Podczas wypraw wojennych i bitew śpiewacy poprzedzali oddziały izraelskie, śpiewając na cześć Pana (2 Krn 20,21). Z dźwiękiem pieśni na ustach wojska wyruszały do bitwy (2 Mch 12,37). Pieśni rozlegały się na cześć powracających ze zwycięskiej bitwy, jak w przypadku Dawida po pobiciu Goliata (1 Sm 18,6-8; 21,12; 29,5), witając wojska machabejskie wkraczające do Gezer (1 Mch 13,47) lub wkraczające do Akry w Jerozolimie (1 Mch 13,51). Bardzo często pieśni zwycięstwa wyrażają dziękczynną modlitwę i uwielbienie. Śpiewy towarzyszyły także uroczystym pożegnaniom ( $\mathrm{Rdz} 31,27)$. Dźwięki pieśni akompaniowały koronacji króla (2 Krn 23,13), a także pogrzebowi królewskiemu (2 Krn 35,25 Jr 34,5).

Śpiew pełnił ważną rolę w liturgii izraelskiej jeszcze przed wybudowaniem świątyni w Jerozolimie. Na tym polu szczególne zasługi należą do wspomnianego już króla Dawida, któremu przypisano tytuł „śpiewaka psalmów Izraela"(2 Sm 23,1). On ustanowił funkcję śpiewaków spośród Lewitów (1 Krn 6,16-32;). Śpiewacy byli zwolnieni z innych lewickich obowiązków, ponieważ ich służba trwała dniem i nocą, co podkreśla ważność tej funkcji (1 Krn 9,33). Byli oni już obecni podczas przeniesienia Arki Pana do Jerozolimy (1 Krn $15,27)$ i potem przy poświęceniu nowo wybudowanej świątyni (2 Krn 5,12-13; 7,6). Ich zadaniem było wielbić Boga psalmami (1 Krn 16,7-37). Jak podaje tekst biblijny, pierwotny chór świątynny składał się z dwustu osiemdziesię-

2 Chodzi o pierwszy raz, kiedy faktycznie wykonywany jest śpiew, a nie tylko o wzmiankę o śpiewie jak w Rdz 31,27.

3 Już samo Wj 15,1-21 jest klasyczną pieśnią zwycięstwa - mówi o zwycięstwie Boga nad wrogimi siłami zagrażającymi Narodowi Wybranemu.

4 Co w tym przypadku było nie tylko aktem odnowienia kultu, ale też zwycięstwem nad narzuconą z zewnątrz obcą religią (1 Mch 1,41-64). 
ciu ośmiu ${ }^{5}$ śpiewaków i instrumentalistów (1 Krn 25,7). O znaczeniu śpiewu w kulcie Boga może świadczyć fakt, że ilekroć ten kult w Izraelu przechodził kryzys, tylekroć upadała posługa śpiewaków. Podobnie odnowieniu kultu towarzyszyło także wznowienie tej posługi (2 Krn 29,25-27; 31,2; 35,15-16;).

Największy skarbiec śpiewów liturgicznych Izraela stanowi Księga Psalmów, której autorstwo tradycja przypisuje Dawidowi. Bez względu na to, jaka część księgi jest autentycznym jego dziełem, tradycja ta wskazuje na wielkie zasługi, jakimi król przyczynił się do rozwoju muzyki Izraela. Psalmy obejmują zarówno tematykę radości, dziękczynienia, pochwały i uwielbienia, jak również żalu, skargi, lęku czy pouczenia. Z pewnością towarzyszyły one Izraelitom nie tylko w kulcie, ale i w życiu prywatnym. Część z nich zawiera informacje na temat autorstwa melodii, na jaką powinny być wykonywane, instrumentów, które powinny akompaniować, technik wykonawczych, a także okoliczności, w jakich powstały ${ }^{6}$. Psalm 68 przekazuje świadectwo uroczystych procesji na cześć Pana. Na czele mieli iść śpiewacy, później dziewczęta z bębenkami, a na końcu harfiarze (Ps 68, 26).

Teksty biblijne mówią także o świeckich śpiewakach i śpiewaczkach (2 Krn 35,25; Ezd 2,65; Ne 7,67; Koh 2,8). Chodzi tutaj zapewne o niewolników, których zadaniem było dostarczanie rozrywki i przyjemności, a dotyczyło to w szczególności dworu królewskiego. O śpiewaczkach Mądrość Syracha wyraża się niepochlebnie, przestrzegając, by nie wchodzić $\mathrm{w}$ relację $\mathrm{z}$ taką kobietą (Syr 9,4).

Śpiew towarzyszył także trudnym momentom historii Izraela. Wyrażał on wdzięczność Bogu za łaskę okazaną ludziom w trudnym położeniu. Tak było w przypadku Tobiasza uzdrowionego ze ślepoty (Tb 12,18-22). Młody Jeremiasz wzywał, by śpiewać Panu w podzięce za swoje wybawienie ze spisku, który został przeciw niemu zawiązany (Jr 20,13). Do wznoszenia pieśni zachęcał również Izajasz (Iz 12,5; 27,2; 42,10; 52,9; 54,1). Na końcu czasów będą śpiewać odkupieni przez Boga, wyzwoleni z utrapień i smutku (Iz 26,1; 35,10; 51,11; $65,14)$.

5 Ciekawym spostrzeżeniem może być fakt, że liczba dwieście osiemdziesiąt osiem stanowi wielokrotność liczby dwanaście, będącej symbolem dwunastu pokoleń Izraela. Może to podkreślać reprezentacyjną funkcję, jaką pełnili śpiewacy przed Bogiem wobec całego Ludu Bożego. Por. L. Ryken, J.C. Wilhoit, T. Longman III, Słownik symboliki biblijnej. Obrazy, symbole, motywy, metafory, figury stylistyczne i gatunki literackie w Piśmie Świętym, s. $172-173$.

6 Zob. Ps 4-6; 8-9; 22; 45-46; 53-62; 67; 69; 75-77; 80-81; 84; 88. 
Pieśni miały także wzywać do nawrócenia (Ez 19,1). Śpiew na cześć Boga ukazywany jest jako przymiot ludzi mądrych, czyli pobożnych (Syr 39,14). Prorok Amos potępił śpiewających fałszywie (Am 6,5).

W Nowym Testamencie pierwszą wzmiankę o śpiewie można spotkać w Ewangeliach. Po zakończeniu swojej ostatniej wieczerzy, Jezus odśpiewał hymny wraz ze swoimi uczniami (Mt 26,30; Mk 14,26).

Śpiew służył jako narzędzie modlitwy dla pierwotnego Kościoła. Paweł, przebywając w więzieniu z Sylasem, modlił się, śpiewając (Dz 16,25). On sam wielokrotnie zachęcał wierzących do śpiewu, zwłaszcza psalmów, hymnów i pieśni pełnych ducha (Ef 5,19; Kol 3,16), by w ten sposób wzajemnie umacniali swoją wiarę.

Śpiew uznawany był za dar i nierozłączny element każdego nabożeństwa (1 Kor 14,15-26). W Liście Jakuba można znaleźć zachętę do śpiewania hymnów, gdy odczuwa się radość (Jk 5,13).

Wielokrotnie ze śpiewem można spotkać się w Księdze Apokalipsy. Zbawieni z wizji śpiewają przed Bogiem i przed Barankiem pieśń nową oraz pieśń Mojżesza i Baranka (Ap 5,9;14,3;15,3), a nie ma tam już żadnej innej pieśni ani innej muzyki (Ap 18,22).

Pierwszą wzmiankę o instrumentach muzycznych w ogóle, znaleźć można w Rdz 4,21, gdzie mowa jest o Jubalu, od którego pochodzą muzycy grający na cytrze i flecie. Cały Stary Testament jest bogatym źródłem wiedzy o tym, jakich instrumentów używano i kiedy. W omówieniu tej tematyki przydatny jest tradycyjny podział rodzajów instrumentów ${ }^{7}$. Najpierw więc zaprezentowane są instrumenty strunowe oraz ich użycie. Następnie instrumenty dęte, a na samym końcu perkusyjne.

Instrumentami strunowymi, które można spotkać w Biblii są cytra, harfa, lira oraz lutnia. Instrumenty te najczęściej stosowano w użytku liturgicznym, ale nie tylko. Przygrywano na nich także w czasie przywitań i pożegnań ( Rdz 31,27), na dworze królewskim i w czasie uczty. Harfa i cytra były przymiotem proroków (1 Sm 10,5; $2 \mathrm{Krl}$ 3,15). Instrumenty stosowano także w celach terapeutycznych. Saul był męczony przez „złego ducha zesłanego przez Boga”. Aby przynieść ulgę cierpiącemu królowi, Dawid przygrywał na cytrze (1 Sm $16,16-23 ; 18,10 ; 19,9)$. Na instrumentach strunowych grano, podczas przenoszenia Arki Pańskiej do Jerozolimy (2 Sm 6,5; 1 Krn 13,8; 15,15-28).

Dla harf, cytr, lir oraz lutni znajdowano szerokie zastosowanie w liturgii izraelskiej. Wspomniano już, że król Dawid ustanowił śpiewaków spośród lewitów. Wśród nich byli także instrumentaliści (1 Krl 10,12; $1 \mathrm{Krn}$ 16,4-7; 1 Krn 25,1-6). Mieli oni wyznaczone miejsce w świątyni na wschód od ołtarza

7 Zob. P.A. Scholes, The Oxford Companion to Music, s. 516. 
(2 Krn 5,12; 29,25). W liturgii instrumenty pełniły głównie funkcję akompaniującą. Psalmy stanowią tego doskonałe świadectwo. Jak było już to wcześniej wspomniane, niektóre z nich posiadają szczególne instrukcje, dotyczące między innymi instrumentów, przy dźwięku których mają być wykonywane. Kilka Psalmów jest przeznaczonych na instrumenty strunowe (Ps 4,1; 6,1; 54,1; 55,1; $61,1 ; 67,1 ; 76,1)$. Wiele także w swojej treści wspomina o ich użyciu, wzywa do chwalenia Boga za pomocą harfy o dziesięciu strunach, cytry, liry i lutni (Ps 33,2; 43,4; 45,9; 49,5; 57,9; 68,26; 71,22; 81,3; 92,4; 98,5; 108,3; 137,2; 144,9; $147,7 ; 149,3 ; 150,3-4)$. Lewici-muzycy służyli nie tylko w świątyni. Dźwięk ich instrumentów uświetniał uroczystość poświęcenia odbudowanych murów Jerozolimy (Ne 12,27).

Instrumenty strunowe kojarzone są w Biblii z radością. Brak ich dźwięku oznaczał opustoszenie, samotność i żal (1 Mch 3,45). Ich dźwięk rozbrzmiewający ponownie ukazywał odnowienie, jak w przypadku oczyszczenia świątyni (1 Mch 4,54), czy odzyskania zamku w Jerozolimie (1 Mch 13,51). Również Hiob przytacza harfę jako symbol szczęścia i radości (Hi 21,12), a gdy mówi o jej smutnym dźwięku wskazuje na skalę swojego nieszczęścia (Hi 30,31).

Prorok Izajasz wymienia harfy i cytry jako narzędzia beztroskiej zabawy (Iz 5,12). Zniszczenie tych instrumentów oznacza upadek $(\mathrm{Iz} 14,11 ; 24,8)^{8}$. Cytry będą jednak znakiem radości dla Izraelitów, gdy Bóg będzie karał narody, które ich ciemiężyły (Iz 30, 32). Księga Daniela wymienia harfy, lutnie oraz psalterium wśród innych instrumentów, które służyły kultowi pogańskiemu w Babilonie (Dn 3,5.7.10.15). Prorok Amos wskazuje, że muzyka ma wyrażać wewnętrzną postawę (Am 5,23) i nie może być wykonywana niedbale (Am 6,5).

Jak widać, instrumenty strunowe towarzyszyły najczęściej liturgii, oraz momentom radości i zwycięstwa, ale również beztroski. Ich uciszenie oznaczało jednak tragedię, upadek i żałobę.

Pierwszy raz o użyciu instrumentów strunowych w NT wspomniano w Pierwszym Liście do Koryntian, gdy autor porównał użycie charyzmatów do koncertu cytry i fletu (1 Kor 14,7). Ma być zachowany taki porządek, aby można było rozróżnić poszczególne proroctwa tak, jak podczas koncertu powinno dać się rozróżnić frazy poszczególnych instrumentów.

Pozostałe wzmianki o instrumentach strunowych można spotkać w Apokalipsie. Zbawieni wyposażeni są w harfy Boże (Ap 5,8;15,2), którymi akompaniują swój śpiew (Ap 14,2-3). Żadnych innych instrumentów oprócz tych już nie ma (Ap 18,22).

Bębny i bębenki, cymbały i grzechotki służyły najczęściej jako akompaniament dla tańca, do wyrażania radości. Księga Rodzaju wspomina o zwyczaju

8 Podobnie jest w Ez 26,13. 
uroczystych pożegnań. Gdy Jakub opuścił potajemnie Labana, ten zarzekał się, że odprawiłby go z pieśniami, z grą cytr i bębnów (Rdz 31,27). Towarzyszyły one pieśni i tańcowi Miriam, po przejściu przez Morze Czerwone (Wj 15,20). Przy dźwiękach bębenków tańczyła również córka Jeftego, gdy ten wracał ze zwycięskiej bitwy nad Ammonitami (Sdz 11,34). Harfy, flety, bębny i cytry należały do wyposażenia grupy proroków, których miał napotkać Saul wewnątrz Gibea Bożego (1 Sm 10,5). Kobiety, witające powracających z bitwy nad Filistynami Dawida i Saula, tańczyły przy akompaniamencie bębnów i cymbałów (1 Sm 18,6). Przy tych instrumentach, a także przy cytrach, harfach i grzechotkach, radośnie skakał i pląsał również król Dawid, gdy przenoszono Arkę Boga do

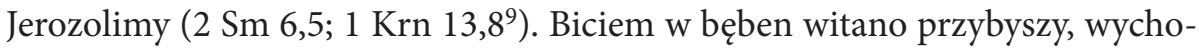
dząc im naprzeciw (Jdt 3,7; 1 Mch 9,39). O bębnie, cytrze i dźwięku piszczałek wspomina udręczony Hiob, mówiąc o szczęśliwym życiu grzeszników, którzy śpiewają radośnie przy ich muzyce(Hi 21,12). Bębenki i cymbały towarzyszyły uroczystościom religijnym (Ps 68,26; 81,3; 149,3 150,4-5). Ich dźwięk akompaniował uwielbieniu Boga (Jdt 16,1).Wraz z fletami, harfami i cytrami przygrywano na nich podczas uczty (Iz 5,12). W proroctwach naród izraelski będzie cieszył się przy ich dźwięku, gdy Bóg będzie karać obce narody (Iz 30,32), gdy dokona On dzieła odnowienia (Jr 31,4).

Jak łatwo zauważyć, instrumenty perkusyjne służyły do wyrażania radości, dlatego akompaniowały pieśniom radości i uwielbienia. Były także obecne podczas spotkań i uczt, oraz przygrywały do tańca.

O użyciu i wystąpieniu instrumentów perkusyjnych można znaleźć tylko jedną wzmiankę. W Pierwszym Liście do Koryntian, Paweł porównuje posiadanie niezwykłych darów duchowych, przy jednoczesnym braku miłości, do pustego dźwięku cymbałów (1 Kor 13,1).

Instrumenty dęte, zwłaszcza trąby i rogi, na ogół służyły w celach sygnalizacyjnych. Głosem trąby Bóg zwołał Izraelitów na zgromadzenie wokół Góry Synaj, gdy rozmawiał z Mojżeszem (Wj 19, 13-19; 20,18). Jej dźwięk budził lęk wśród ludzi stojących u podnóża góry. Zgodnie z Prawem, dęto w róg, gdy zwoływano zgromadzenie, z okazji świąt Paschy, Przaśników, święta Tygodni, świąt nowiu, Dni Przebłagania czy święta Namiotów (Kpł 23,24; 25,9; Lb 29,1). Księga Liczb mówi o dwóch srebrnych trąbach, które służyły zwoływaniu ludu lub dawaniu sygnału do zwinięcia obozu (Lb 10,1-10).

Trąby i rogi znajdowały zastosowanie militarne. Ich dźwięk towarzyszył oblężeniu Jerycha, którego mury rozpadły się pod wpływem natężenia dźwięku (Joz 6,1-21). Trębacze (najczęściej kapłani) wchodzili w skład oddziałów

9 Ta perykopa wśród instrumentów wymienia również lutnie i trąby, nie mówi jednak o grzechotkach. 
izraelskich $(2 \mathrm{Krn} 13,12)$. Gdy rozlegał się głos trąby, wojska rozpoczynały natarcie (Lb 31,6; Sdz 3,27; 2 Krn 13,14; 1 Mch 4,13.40; 6,33; 7,45; 9,12; 16,8; 2 Mch 15,25). Róg dawał sygnał do zgromadzenia wojsk oraz przerwania walki (Sdz 6,34; 2 Sm 2,28; 18,16;). Trąba alarmowała mieszkańców miasta o zbliżającym się zagrożeniu ze strony napastników (Ne 4,14; Am 3,6). Jej głos często był kojarzony z toczącą się bitwą (1 Mch 5,31.33; Hi 39,24-25). Przeciągły dźwięk budził u wrogów przerażenie, co wykorzystał Gedeon (Sdz 7,8-22). Gdy szedł wraz z trzystu wybranymi do walki przeciw Madianitom, kazał zabrać każdemu dzbany, pochodnie oraz właśnie rogi. Wszyscy w obozie wroga wpadli w popłoch i zwrócili się jeden przeciw drugiemu. Odgłos trąb wyrażał radość powracającego, zwycięskiego wojska (2 Krn 20,28).

Innym rodzajem sygnałów, do jakich wykorzystuje się w Biblii trąby i rogi, stanowią różne obwieszczenia i ogłoszenia. Saul głosem trąby ogłosił w całym kraju zwycięstwo swojego syna Jonatana nad Filistynami (1 Sm 13,3). Dźwiękiem tychże instrumentów obwieszczano koronację nowego króla (2 Sm 15,10; $1 \mathrm{Krl}$ 1,34.39; $2 \mathrm{Krl}$ 11,14; $2 \mathrm{Krn}$ 23,13). Szeba, syn Bikriego, użył rogu, aby zwrócić na siebie uwagę, gdy postanowił zbuntować się przeciw Dawidowi (2 Sm 20,1).

Trąba i róg stosowane były w liturgii. Jeszcze zanim powstała świątynia Pańska, rogi ${ }^{10}$ grały na cześć Boga podczas przenoszenia Arki do Jerozolimy ( 2 Sm 6,$15 ; 1$ Krn 13,$8 ; 15,24.28$ ). Granie na trąbach należało do czynności kapłańskich (1 Krn 15,24; 2 Krn 5,12), chociaż pełnili ją także lewici (1 Krn 16,6). Trębacze w świątyni stali na wschód od ołtarza wraz z innymi instrumentalistami (2 Krn 5,12). Grali oni wspólnie na cześć Pana podczas wniesienia Arki do Świątyni (2 Krn 5,11-14), oraz poświęcenia tej drugiej (2 Krn 7,6), a także gdy rozpoczęto jej odbudowę po niewoli babilońskiej z okazji założenia fundamentów (Ezd 3,10). Dźwiękiem trąb i rogów wyrażano złożenie uroczystej przysięgi wobec Boga (2 Krn 15,14). Towarzyszyły one także uroczystym ofiarom (2 Krn 29,26-28). Po powrocie z niewoli, Izraelici zaczęli odbudowę Jerozolimy. Głos trąb, a także innych instrumentów, akompaniował uroczystości poświęcenia jej murów (Ne 12,27-43). Nie zawsze jednak dęto w trąby przy radosnych obchodach. Czasem towarzyszyły one pełnym żalu, smutku i przerażenia prośbom o wybawienie kierowanym do Boga (1 Mch 3,54; 4,40). Trąby i rogi pojawiają się także w Psalmach mówiących o wielkich i radosnych uroczystościach, w trakcie których najpewniej były też wykonywane (Ps 47,6; 81,4; 98,6; 150,3). O użyciu kutych trąb przy składaniu ofiar mówi Księga Mądrości Syracha, gdy opowiada historię arcykapłana Szymona (Syr 50,16).

10 Trąby według 1 Krn 13,8; 15,24.28. 
Trąba i róg często występują w księgach prorockich. Izajasz skojarzył ich dźwięk z wojną, jaką Bóg wypowiada obcym narodom, z ostatecznym wybawieniem, którego dokona na Izraelu (Iz 18,3; 27,13). Do trąby został porównany głos proroka wytykającego grzechy narodowi wybranemu (Iz 58,1). U Jeremiasza trąba związana była z groźbami przeciw Izraelowi i Judzie, z zapowiedzią nadchodzącej wojny, najazdu babilońskiego, jeśli lud się nie nawróci (Jr 4,5.19.21; 6,1.17). Naród wybrany został tam przedstawiony jako ten, który nie chce słyszeć głosu trąby i woli zaufać Egiptowi niż Bogu (Jr 42,14). Jeremiasz kazał dąć w trąby także przeciw Babilonowi, zapowiadając jego upadek (Jr 51,27). W Księdze Ezechiela, proroka porównano do stróża, którego zadaniem jest dąć w trąbę, jeśli widzi nadchodzącego wroga (Ez 33,3-6). U proroka Daniela rogi, flety i dudy zostały wymienione wśród instrumentarium służącemu bałwochwalczemu kultowi złotego posągu (Dn 3,5.7.10.15). Prorok Ozeasz mówił o głosie rogu w Gibea i trąby w Rama (Oz 5,8). Po raz kolejny pojawiło się także porównanie proroka do stróża, mającego dąć w róg $(\mathrm{Oz} 8,1)$. W Księdze Joela można znaleźć wezwanie, aby zadąć w róg, co ma zwiastować nadejście dnia Pańskiego (Jl 2,1), a także rozpoczęcie okresu postu i pokuty (Jl 2,15). Przy dźwięku rogu, czyli w wojnie zniszczony ma zostać Moab w Księdze Amosa (Am 2,2). Według proroka Sofoniasza trąba ma zabrzmieć w dzień straszliwego sądu Bożego (So 1,16). Zachariasz zaś zapowiedział, że dźwięk rogu oznajmi nadejście Boga, który ocali swój lud (Za 9,14).

Flety i piszczałki często występowały wraz z instrumentami strunowymi i podobnie jak harfa były wyrazem radości. Flety należały do instrumentarium wędrownych proroków, których spotkał Saul (1 Sm 10,5). Towarzyszyły także radości z koronacji Salomona (1 Krl 1,40). Brak dźwięku fletu i piszczałek oznaczał żałobę (1 Mch 3,45). Nie móc cieszyć się przy ich dźwięku oznaczało tragedię (Hi 30,31; Jr 48,36). Dźwięki fletu kojarzono z radością (Iz 30,29; Hi 21,12).

Wielokrotnie w NT można napotkać nawiązania i opisy użycia instrumentów dętych, a zwłaszcza trąb i ich sygnalizacyjnej funkcji.

Jezus przestrzegł, by nie trąbić przed sobą, gdy daje się jałmużnę (Mt 6,2). $\mathrm{Na}$ końcu czasów na dźwięk trąby aniołowie zbiorą wybranych Boga z całego świata (Mt 24,31) , powstaną umarli, a żyjący będą odmienieni (1 Kor 15,52), a Pan zstąpi z nieba (1 Tes 4,16).

Paweł porównał nietłumaczone proroctwa w językach do niepewnej gry na trąbie, na którą nikt nie zwraca uwagi, ani nie rozumie jej znaczenia (1 Kor $14,8)$.

Do głosu trąby często porównywany jest głos Boga (Hbr 12,14, Ap 1,10; 4,1). Apokalipsa mówi, że będą one atrybutami aniołów, którzy będą grali na nich sygnalizując poszczególne etapy wypełniania się czasów (Ap 8,1-13; 9,14; 10,7). 
Oprócz trąb spotkać można także flet, fletnię. Fletniści byli wśród muzyków orszaku pogrzebowego, gdy Jezus przyszedł, aby wskrzesić córkę Jaira (Mt 9,23).

Taniec jest powszechnie obecny na kartach Starego Testamentu. Występuje on w wielkich i podniosłych momentach, ale także w zwyczajnej codzienności. Taniec jest wyrazem radości. Często występuje z akompaniamentem instrumentów muzycznych, takich jak: flet, cytra, bębny i cymbałki.

Po raz pierwszy taniec można spotkać w Księdze Wyjścia, gdy Izraelici przeszli przez Morze Czerwone. Inicjatorką tańca była tam Miriam, siostra Mojżesza i Aarona, która przy dźwięku bębenków podrywała do pląsów także inne kobiety za sobą (Wj 15,20). W tej samej księdze taniec został pokazany także w swoim bałwochwalczym aspekcie. Izraelici, zniecierpliwieni długim pobytem Mojżesza na Górze Horeb, wykonali cielca ze złota i ogłosili go swoim bogiem, a później na jego cześć wykonali radosne tańce (Wj 32,19). Tańcem kobiety witały powracających zwycięzców. Tak było w przypadku Jeftego, gdy pobił Ammonitów (Sdz 11,34), a także w przypadku Dawida po walce z Goliatem (1 Sm 18,6-7; 21,12; 29,5). Księga Sędziów wspomina o zwyczaju praktykowanym w Szilo, według którego dziewice z okazji Święta Namiotów ${ }^{11}$ wychodziły, by wspólnie tańczyć, co miało być symbolem ich gotowości do zamążpójścia ${ }^{12}$ (Sdz 21,21-23).

Taniec wykorzystywany był także w liturgii. Za jego pomocą wychwalano Boga, oraz wyrażano radość wobec Niego, dlatego król Dawid tańczył przed Arką podczas jej przenoszenia do Jerozolimy (2 Sm 6,5-21; 1 Krn 13,8; 15,29). O liturgicznym użyciu tańca wspominają także Psalmy (Ps 149,3; 150,4). Podobnie było w pogańskich kultach ościennych. Prezentację tego mamy w opowieści o konfrontacji Eliasza z prorokami Baala (1 Krl 18,26).

Miasta Tyru i Sydonu, Sur, Okiny, Jamnii, Aszdodu, Aszkelonu i Gazy przyjęły tańcem wojska Nabuchodonozora, wyrażając w ten sposób uległość (Jdt 3,7). Izraelici tańczyli po zwycięstwie Judyty nad Holofernesem (Jdt 15,12-13). Taniec ukazano jako wyraz i synonim radości i szczęścia (Hi 21,12; Ps 30,12; Koh 3,4; Lm 5,15; Ez 7,7). Prorok Jeremiasz zapowiedział, że Naród Wybrany będzie tańczył z radości przy odnowieniu, jakiego Bóg na nim dokona (Jr 31,4.13).

11 Wg M. O’Connor, Księga Sędziów, w: Katolicki komentarz biblijny, s. 234.

12 Por. S. Niditch, Judges, w: The Oxford Bible Commentary, s. 191. 
Niewiele znaleźć można wzmianek na temat tańca w NT. Raz tylko jest elementem narracji, a dwa razy występuje w przypowieściach Jezusa.

Córka Herodiady wykonała taniec dla Heroda i jego gości, aby w ten sposób skłonić go do stracenia Jana Chrzciciela (Mt 14,1-12; Mk 6,17-29). Jezus w jednej z przypowieści porównał ludzi mu współczesnych do dzieci, które nawzajem do siebie mówią: „Przygrywaliśmy wam a wy nie tańczyliście" - opisując w ten sposób niechęć ludzi do przyjęcia Jego nauki (Mt 11,17; Łk 7,32).

Ostatnia wzmianka dotycząca tańca znajduje się w przypowieści o miłosiernym ojcu. Gdy starszy syn, kończąc pracę w polu, przybył do domu, trafił na przyjęcie z okazji powrotu jego brata. Podczas tego przyjęcia goście tańczyli przy muzyce (Łk 15,25).

Śpiew, dźwięk instrumentów, taniec jest istotnym elementem wydarzeń biblijnych. Tekst przytacza liczne tego świadectwa. Tym samym oznacza to, że muzyka była ważną częścią życia bohaterów biblijnych. Podobnie jak ważna była w innych kulturach. Znamienne jest, że w większości przykładów muzyka posiada odniesienie do Boga. Śpiew, gra szerokiej gamy instrumentów i radosny taniec są elementem kultu świątynnego, uwielbienia, dziękczynienia, modlitwy, jaką przez całą historię biblijną, ludzie zanoszą do Pana. Towarzyszą wydarzeniom politycznym, takim jak koronacja nowego króla. Są obecne przy uroczystościach religijnych. Zagrzewają wojsko do walki i wyrażają radość ze zwycięstwa. Umilają życie codzienne. Są także obecne w proroctwach. Ważną wskazówką, jaką daje tekst natchniony, jest ukazanie, jak zmienia się muzyka wraz ze zbliżeniem, bądź oddaleniem ludu od Boga. Posłuży ona w dalszej analizie tekstu.

\section{Pieśń Mojżesza i Baranka}

Pragnąc przedstawić znaczenie muzyki w tekście biblijnym, do tej pory zidentyfikowano wszystkie te perykopy, gdzie towarzyszy ona opisywanym wydarzeniom. Następująca część wywodu koncentruje się na egzegezie Ap 15,2-4.

Przed przystąpieniem do egzegezy warto wyznaczyć granice perykopy. W tym celu należy określić kontekst poprzedzający i następujący, ustalić miejsce tekstu w strukturze księgi. Przydatne jest także porównanie różnych polskich przekładów Pisma Świętego, Neowulgaty oraz tekstu greckiego, który służy jako źródło dla dalszej analizy. Można także sprawdzić jaką postać ma perykopa w czytaniach liturgicznych.

Głównym elementem delimitacji jest zbadanie kontekstu poprzedzającego oraz następującego dla danej perykopy oraz jej miejsca w ogólnej strukturze 
księgi. Badany tekst należy do wizji proroczych ${ }^{13}$. Jest także jedną z ostatnich dotyczących siedmiu pieczęci, siedmiu trąb oraz siedmiu czasz ${ }^{14}$. Perykopa poprzedzona jest wizją żniwa, zebrania owocu winorośli i gniewu Bożego. Kontekst następujący dotyczy siedmiu aniołów, mających czasze z siedmioma plagami.

Warto w tym miejscu zauważyć, że większość zmian akcji w Apokalipsie

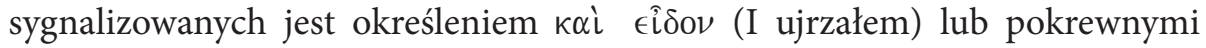
(np. 13,1;13,11;14,1;14,6;15,1) ${ }^{15}$. W badanej perykopie sformułowanie to występuje dwukrotnie (15,1 i 15,2), co sugeruje, że należałoby traktować 15,1 oraz 15,2-4 jako osobne jednostki literackie ${ }^{16}$. Tezę tę zdaje się potwierdzać kontekst bezpośrednio następujący, mówiący o siedmiu aniołach, czaszach i plagach $(15,5$ - 16,21), będący ściśle związany tematycznie z 15,17. Fragment 15,2-4 sprawia wrażenie wtrąconego, co może świadczyć, że jest on późniejszym dodatkiem ${ }^{18}$.

Biblia Tysiąclecia oraz Biblia Edycji Świętego Pawła jako granice perykopy wskazuje 15,1-4. Biblia w przekładzie ks. Jakuba Wujka oraz Biblia Warszawsko-Praska zalicza do perykopy cały rozdział 15 . Podobnie jest w Neowulgacie. Novum Testamentum Graece natomiast zdaje się dzielić werset 1 oraz 2-4 na osobne jednostki.

W Lekcjonarzu Mszalnym perykopa ta, w układzie 15,1-4 występuje tylko raz, w środę trzydziestego czwartego tygodnia okresu zwykłego w cyklu drugim.

W niniejszym studium do egzegezy służy tekst w granicach 15,2-4. Przedstawione powyżej informacje pokazują, że można rozpatrywać podany fragment jako oddzielną perykopę. Jest on także zgodny z tematem badań.

13 Posłużono się tutaj strukturą zaproponowaną przez A. Jankowskiego. Por. idem, Apokalipsa Świętego Jana: wstęp, przekład z oryginału, komentarz, s. 131-132.

14 Por. ibidem.

15 Por. ibidem, s. 231.

16 Por. M. Wojciechowski, Apokalipsa Świętego Jana: objawienie, a nie tajemnica. Wstęp, przekład $z$ oryginatu, komentarz, s. 308-309. Autor do granic perykopy zalicza cały rozdział 15 , jednak dzieląc ją na 3 sekcje $(15,1 ; 15,2-4 ; 15,5-8)$ wskazuje na luźny związek tej środkowej z pozostałymi.

17 Por. R. Bauckham, Revelation, w: The Oxford Bible Commentary, s. 1299.

18 Por. ibidem; A.Y. Collins, Apokalipsa św. Jana, w: Katolicki komentarz biblijny, s. 1563. 
Następnym krokiem przygotowującym egzegezę jest przeprowadzenie krytyki tekstu oryginalnego oraz jego przekład na język polski. Dla większej wygody, tekst grecki zostaje w tym miejscu w całości przytoczony ${ }^{19}$ :

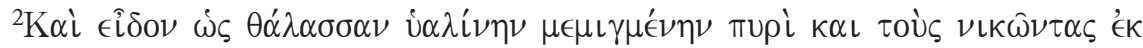

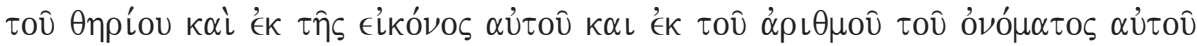

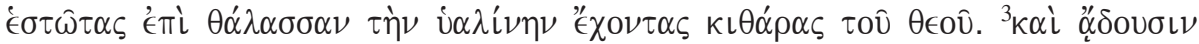

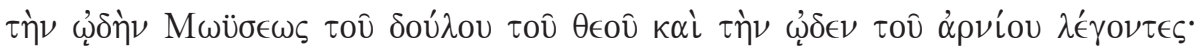

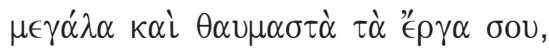

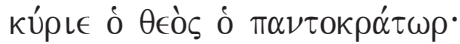

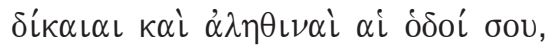

ò $\beta \alpha \sigma \iota \lambda \epsilon \dot{v} \varsigma \tau \hat{\omega} \nu$ '̇ $\theta \nu \omega \hat{\omega} \nu$.

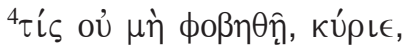

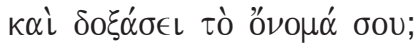

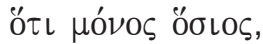

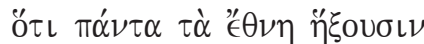

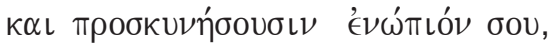

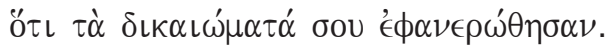

$\mathrm{W}$ tym miejscu są przedstawione różne warianty ${ }^{20}$ dla podanego powyżej tekstu. Zostały one pogrupowane osobno dla każdego wersetu.

W wersecie 2 można wymienić następujące warianty:

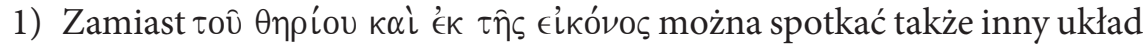

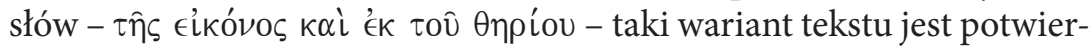
dzany przez tekst bizantyjski.

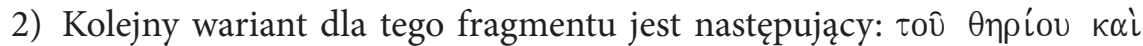

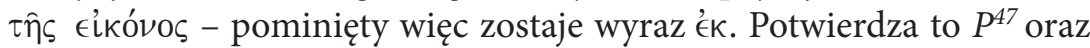
Kodeks Synajski.

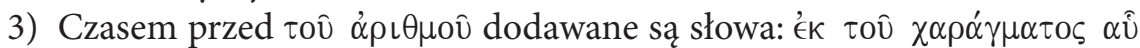

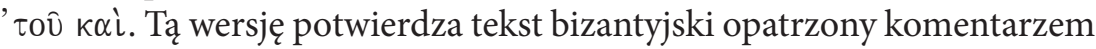
Andrzeja z Cezarei a także Kodeks 051.

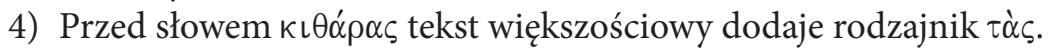

5) W tym samym miejscu, lecz za omawianym słowem Kodeks Synajski dodaje kupíou.

W wersecie 3:

19 Tekst grecki pochodzi z: Novum Testamentum Graece. Pominięto znaki aparatu krytycznego.

20 Na podstawie aparatu krytycznego. Por. ibidem, s. 662. 


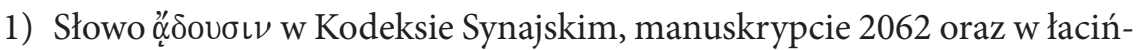
skich kodeksach 61,55 i w Wulgacie w wydaniu Wordswortha-White'a jest zastąpione formą ớ $\delta 0 \nu \tau \alpha \varsigma$. W tej formie tekst cytują także Prymazjusz z Hadrumentum oraz Beatus z Liébany.

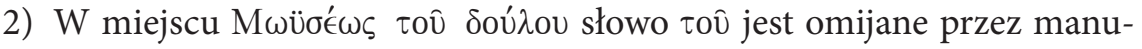
skrypty 1006, 1841, 1854 oraz tekst bizantyjski.

3) Zamiast ò $\beta \alpha \sigma \iota \lambda \in \dot{u} \varsigma$ Kodeks Synajski oraz manuskrypt 1854 umieszczają inną formę słowa, mianowicie $\beta \alpha \sigma \iota \lambda \in \hat{v}$.

4) Słowo ' $\theta \nu \omega \hat{\omega} \nu P^{47}$, Kodeks Synajski, Kodeks Efrema, manuskrypty 1006, 1611, syryjskie i sahidyckie zastępują słowem $\alpha i \omega \nu \omega \hat{\nu}$.

1) Natomiast za '€́ $\theta \omega \hat{\nu} \nu$ przemawiają wcześniejsze wersje Kodeksu Synajskiego, Kodeks Aleksandryjski, 051, tekst większościowy, łaciński kodeks 51, tekst harkleański i tekst bohairycki. W tej formie cytowany jest również przez Prymazjusza.

W wersecie 4:

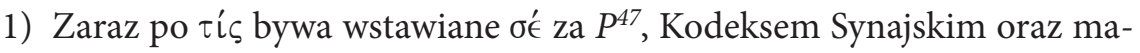
nuskryptami 1006, 1841, 1854 i 2329.

2) Synaiticus, 1006 i 1841 pomijają $\mu \grave{\eta}$.

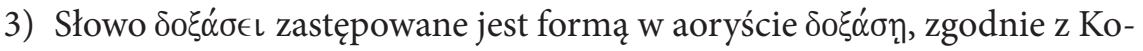
deksem Synajski , manuskryptami 1006, 1611, 1841, 2062 i tekstem więszkościowym.

4) 1854 zastępuje je słowem $\theta \alpha u \mu \alpha ́ \sigma \eta$.

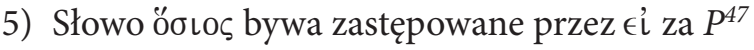

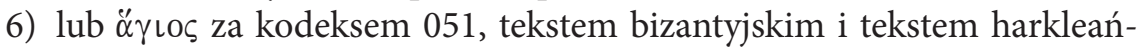
skim $^{21}$.

7) Manuskrypt 2329 i niektóre wersje tekstu harkleańskiego wstawiają

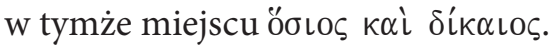

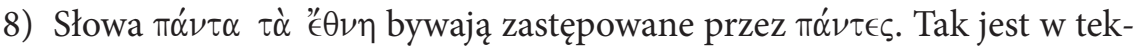
ście bizantyjskim.

9) Manuskrypty 1006 i 1841 umieszczają tam tylko $\pi \alpha ́ \nu \tau \alpha$.

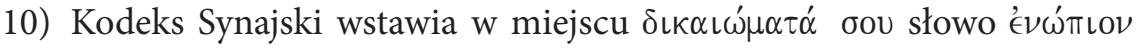
pomiędzy te dwa.

W tym miejscu są przedstawione te warianty, które zostały wybrane dla ustalenia wersji tekstu służącej w dalszej pracy egzegetycznej. Następnie zaprezentowano przekład tekstu. W krytyce posłużono się metodą eklektyzmu dedukcyjnego ${ }^{22}$, czyli wybierania wariantów tekstu zarówno na podstawie świadectw zewnętrznych, na które składa się wiek, jakość i ranga manuskryp-

21 Manuskrypty 1006 i 1841 dodają jeszcze w tym miejscu $\epsilon$. Por. ibidem.

22 Zob. B.D. Ehrman, Przeinaczanie Jezusa. Kto i dlaczego zmieniał Biblie, s. 150-154. 
tów, jak i wewnętrznych, czyli oceny danej lekcji za pomocą kryterium języka, stylu i teologii danej księgi, oraz za pomocą kryterium czytania krótszego lub trudniejszego.

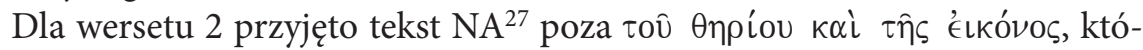
re jest potwierdzone przez wczesne świadectwa o wysokiej randze i przedstawia czytanie krótsze. Pozostałe warianty odrzucono ze względu na niską rangę świadectw (np. tekst bizantyjski) lub prezentowały dłuższą lekcję. Dla wersetu 3 przyjęto warianty 1-3 i 5 ze względu na liczbę i rangę świadectw oraz krótsze czytania. Dla 4 wersu przyjęto opcje 2,3,5 i 9 ze względu na trudniejszą lub krótszą lekcję, oraz ze względu na wiek, wielość i rangę świadectw.

Na podstawie wybranych wariantów, przekład na język polski będzie wyglądał następująco:

${ }^{2}$ I zobaczyłem jakby morze szklane złączone $(\mathrm{z})^{23}$ ogniem i zwyciężających nad Bestią i obrazem jej, i nad liczbą imienia jej, stojących nad morzem szklanym, mających harfy Boga ${ }^{3}$ i śpiewających pieśń Mojżesza, sługi Boga, i pieśń Baranka mówiąc: wielkie i cudowne dzieła Twoje,

Panie Boże Wszechwładco.

Sprawiedliwe i prawdziwe drogi Twoje,

Królu narodów.

${ }^{4}$ Kto nie lękałby się, Panie,

i (nie) wielbił imienia Twojego?

Bo jedyny jesteś,

bo wszystko przyjdzie

i padnie na twarz przed Tobą,

bo wyroki Twoje ujawnione.

Tekst oryginalny i tak sformułowany jego przekład służą w dalszej pracy egzegetycznej. Powyższe tłumaczenie stara się zachować kolejność słów w stosunku do oryginału, a także formy gramatyczne i czas. Interpunkcja jest zastosowana zgodnie z zasadami języka polskiego. Dla zachowania logiki zdań konieczne było dodanie słów w nawiasach okrągłych.

Problem rodzą niektóre słowa, ze względu na ich wieloznaczność. Słowo

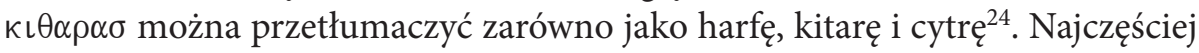

23 Nawiasy okrągłe ( ) oznaczają słowa, które zostały dodane ze względu na sens zdania w języku polskim.

24 Por. R. Popowski, Wielki słownik grecko-polski Nowego Testamentu, Warszawa 1995, s. 338. Najprawdopodobniej chodzi po prostu o instrument strunowy bez dokładnego okre- 
jednak w polskich przekładach występuje tu słowo „harfa”. Postanowiono zachować to tłumaczenie ze względu na jego popularność ${ }^{25}$. Słowo $\theta \alpha \dot{\alpha} \lambda \alpha \sigma \sigma \alpha$ tłumaczyć można zarówno jako „morze”, jak i „jezioro”. Ze względu na widoczne nawiązanie do $\mathrm{Wj} 15$ zachowano to pierwsze znaczenie ${ }^{26}$.

Pewien dysonans może wzbudzić wers „śpiewających pieśń [...] mówiąc”. Jest to jednak zwrot charakterystyczny dla wielu pism NT. Znaczy to tyle samo, co po prostu „śpiewając" i mimo że w języku polskim wydaje się brzmieć niepoprawnie, zostało zachowane, aby jak najwierniej oddać tekst oryginalny.

Przed przystąpieniem do analizy egzegetycznej potrzebna jest analiza struktury tekstu. W tym ustępie przedstawiona jest propozycja, w jaki sposób można podzielić omawiany fragment biblijny, jakie słowa można uznać za najważniejsze, stanowiące klucz do interpretacji tekstu.

Łatwo da się zauważyć, że omawiany tekst składa się z dwóch części. Podział ten rodzi się przez zmianę gatunku literackiego. Wersety $2-3$ do słów „pieśń Baranka mówiąc” stanowią narrację. Następnie rozpoczyna się liryka.

Narrację znów można podzielić na dwie części. Pierwszą (A) jest opis miejsca: „morze szklane złączone z ogniem”. Druga część (B) dotyczy osób: „Zwyciężających nad Bestią”. Fragment liryczny także da się podzielić na kilka części. Na początku zawarty jest zwrot do Boga wychwalający Jego wielkość i sprawiedliwość jego dzieł: „wielkie i cudowne dzieła Twoje...”. Stanowi to część C. Dalej pojawia się pytanie retoryczne: „Kto nie lękałby się...”. Jest to część D. Następne zdanie („Bo jedyny jesteś...”) jest wynikiem postawionego wcześniej pytania i swoją treścią wyraża tę samą myśl, co część C, z tego też powodu można zaklasyfikować je jako C'.

Tak przeprowadzona analiza wykazuje strukturę koncentryczną tekstu: ABCDC. Część centralna D, może stanowić klucz do interpretacji całej perykopy. W tym miejscu można postawić tezę kluczową dla całego wywodu: muzyka - jej jakość i ukierunkowanie - wyraża stan duchowy człowieka, jego relację wobec Boga (zjednoczenie, czy oddalenie).

W przeprowadzanej egzegezie w pierwszej kolejności przedstawiona jest analiza części A, która zawiera opis miejsca, w którym toczy się akcja sceny. Następnie omówiona jest część B, czyli postaci, symbole i przedmioty tam wystę-

ślania jaki to instrument. Więcej na ten temat znajduje się w dalszej części niniejszego studium.

25 Mają tak: Pismo Święte Starego i Nowego Testamentu, Edycja Świętego Pawła, Częstochowa 2008. Pismo Święte Starego i Nowego Testamentu, Wydawnictwo Pallottinum (Biblia Tysiąclecia), Poznań 2007. Biblia warszawsko-praska, Warszawa 1997. Natomiast Biblia w przekładzie ks. Jakuba Wujka z 1599 r., Warszawa 2000, ma tutaj „cytry”.

26 Zob. R. Popowski, Wielki słownik, s. 266. 
pujące - osobne ustępy poświęcone są Bestii, jej obrazowi i liczbie jej imienia, zwycięzcom, harfom oraz samego określenia pieśni. Dalej omówiona jest treść pieśni, czyli części C i C’ oraz D.

W Biblii morze symbolizuje pierwotną materię, którą Bóg wykorzystał do stworzenia świata. Jest źródłem wszystkich wód dla całej ziemi, a także chaosem, który wymaga uporządkowania i umieszczenia w granicach ${ }^{27}$.

Morze symbolizuje także zagrożenie dla Bożych stworzeń i siedlisko potworów ${ }^{28}$. Cały czas napiera na swoje granice próbując zalać świat, przywracając chaos, lecz stale znajduje się pod Bożym panowaniem ${ }^{29}$. Apokalipsa ukazuje morze jako królestwo Bestii i wszelkiego zła ${ }^{30}$.

Szkło jest sztywnym materiałem. Fakt, że morze, w analizowanym fragmencie, składa się właśnie z takiego tworzywa, symbolizuje panujący na nim spokój. Nie jest wzburzone i nie porusza się. Nie ma w nim obecnego zła, które je porusza ${ }^{31}$. Jest zupełnym przeciwieństwem bezładu, jaki panował w pierwotnym bezmiarze wód ( $\mathrm{Rdz} 1,1)$. Ogień, z którym zmieszane jest morze, symbolizuje nadchodzący sąd Boży ${ }^{32}$. Ostatecznie, gdy nastanie „nowe niebo i nowa ziemia” (Ap 21,2) morza, czyli źródła zagrożenia i niepokoju, już nie będzie ${ }^{33}$.

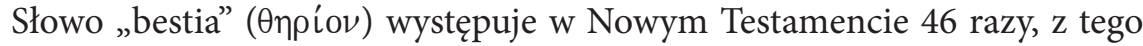
aż 39 w Apokalipsie ${ }^{34}$. Odnosi się ono do dwóch Bestii - tej, która wychodzi z morza (Ap 13,1-10) oraz tej, która wychodzi z ziemi (Ap 13,11-18) ${ }^{35}$. Nie przypominają one żadnych innych stworzeń żyjących na ziemi ${ }^{36}$. Bestie są ucieleśnieniem zła antychrysta i fałszywego proroka, i stanowią przeciwieństwo Baranka ${ }^{37}$.

Której z bestii dotyczy omawiany fragment? Trudno jest dać jednoznaczną odpowiedź, ale najprawdopodobniej dotyczy on pierwszej, która wyszła z morza. Jak wynika z wcześniejszego kontekstu (Ap 13), to ona spełnia ważniejszą rolę. To dla niej sporządzono obraz i liczbą jej imienia naznaczono ludzi ${ }^{38}$.

Por. L. Ryken, J.C. Wilhoit, T. Longman III, Słownik symboliki biblijnej, s. 542-543.

Por. L. Ryken, J.C. Wilhoit, T. Longman III, Słownik symboliki biblijnej, s. 754-758.

Por. ibidem.

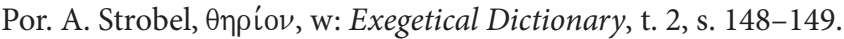

Por. ibidem.
} 


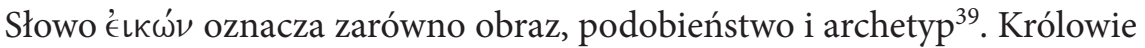
kazali tworzyć sobie wizerunki w podległych im krajach. Był to znak rozciągającej się na ten teren władzy ${ }^{40}$. Tworzono również przedstawienia bogów. Obrazy miały charakter kultyczny. Wierzono, że jest w nich obecny ten, którego przedstawiają $^{41}$.

Kultyczną funkcję spełnia obraz Bestii. Jak ukazuje Apokalipsa, jest to narzędzie kultu (Ap 13,14-15). Każdy, kto nie odda mu czci, musi zostać zabity.

W językach semickich liczby oddaje się za pomocą liter alfabetu. Stąd każde słowo miało swoją wartość liczbową ${ }^{42}$. Nie dziwi więc sformułowanie „liczba imienia".

W Księdze Apokalipsy liczba imienia jest przedstawiana $\mathrm{w}$ formie znamienia (Ap 13,16-18), bez którego nie można prowadzić żadnych interesów ${ }^{43}$. Wartość liczbowa imienia bestii przedstawiona jest jako sześćset sześćdziesiąt sześć (Ap 13,18). Ciągle nie rozszyfrowano jej znaczenia. Istnieją dwie godne uwagi tezy. Jedna głosi, że należy tu odczytywać imię Nerona lub cezara jako boga. Druga z nich nawiązuje do symboliki liczb i głosi, że należy widzieć w tym miejscu trzy szóstki - liczbę przeciwstawianą siódemce, która oznacza doskonałośćc ${ }^{4}$. Znamię Bestii czy liczba jej imienia, stanowią przeciwieństwo dla pieczęci Boga, którą otrzymali Jego słudzy $(\text { Ap } 7,3)^{45}$.

Postaci zwycięzców opisane są za pomocą czterech czynności, mianowicie:

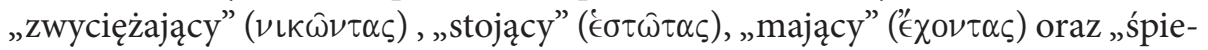
wają" ( są w czasie teraźniejszym. Taka forma sugeruje, iż nie jest to opis dotyczący przyszłości, ani nie dotyczy on tylko zmarłych, lecz wszystkich wierzących żyjących obecnie, walczących ze złem. Równocześnie eschatologiczny charakter sceny wskazuje na już dokonujący się udział chrześcijan w rzeczywistości niebiańskiej ${ }^{46}$.

Użycie słowa „harfa” w przekładzie rodzi pewne problemy. W języku greckim jest tu słowo $\kappa \iota \theta \alpha ́ \rho \alpha$, które w języku polskim można oddać zarówno przez „harfę”, jak również „cytrę” i „kitarę”. Przypuszczalnie chodzi po prostu o instrument strunowy. Śledząc występowanie tego rodzaju instrumentów w Biblii,

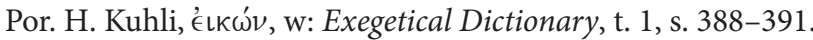

40 Por. K. Pauritsch, Obraz, w: Praktyczny słownik biblijny, s. 860.

41 Por. ibidem.

42 Por. G. Herrgott, Liczba, w: Praktyczny słownik biblijny, s. 651.

43 Por. H. Balz, $\chi \alpha \dot{\alpha} \rho \gamma \gamma \mu \alpha$, w: Exegetical Dictionary, t. 3, s. 455-456.

44 Por. A. Jankowski, Apokalipsa Świętego Jana, s. 221.

45 Por. H. Balz, $\chi \alpha \dot{\alpha} \alpha \gamma \mu \alpha$, w: Exegetical Dictionary, t. 3, s. 455-456.

46 Por. A. Jankowski, Apokalipsa Świętego Jana, s. 231.
} 
można stwierdzić, że w znacznej mierze towarzyszą one chwilom radości (np. przy obchodach świąt itp. ${ }^{47}$. Podobnie jest także w omawianym przypadku. Harfa towarzyszyła śpiewowi psalmów i pieśni. Widoczne jest w omawianej perykopie nawiązanie do liturgii w Świątyni Jerozolimskiej ${ }^{48}$.

Warto zwrócić uwagę na przymiotnik użyty w tekście. Są to „harfy Boga”.

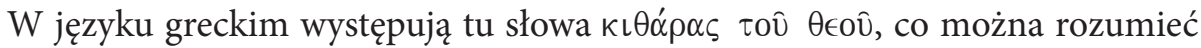
jako określenie przynależności (należące do Boga), a także jakości (boskie). Przymiotnik ten odróżnia harfy używane przez zbawionych od tych, które są używane przez mieszkańców apokaliptycznego Babilonu (Ap 18,22). Jest to więc wskazanie na ich cel. Służą one kultowi prawdziwego Boga ${ }^{49}$. Co więcej, wszyscy posiadają ten sam instrument i śpiewają razem tą samą pieśń, co może wyrażać jedność ${ }^{50}$.

Pieśń nazwana jest Pieśnią Mojżesza. Widoczna jest tu wyraźna typologia Exodusu. Podobnie jak pieśń z Księgi Wyjścia i ta śpiewana jest nad morzem oraz wiąże się z odniesionym zwycięstwem. Równocześnie jednak nazwana jest Pieśnią Baranka, który jest antytypem Mojżesza ${ }^{51}$. Pieśń z Księgi Wyjścia zawierała w sobie pewną tymczasowość, a wraz z nią pragnienie nowej pieśni ostatecznej, po której nie będzie już trosk i zmartwień, lecz tylko pochwalny śpiew $^{52}$. Chrystus jest wypełnieniem tego pragnienia, dlatego jest to pieśń Baranka ${ }^{53}$. Widoczny jest tu także wymiar napięcia eschatologicznego, między rzeczywistością już dokonującą się, a tą, która ma dopiero nastąpić.

Nad Morzem Czerwonym Izraelici śpiewali na cześć Boga z powodu jednorazowego zwycięstwa, wyjścia z niewoli doczesnej. Tutaj wierni śpiewają z powodu zwycięstwa nad Bestią i wyjścia z niewoli zła ${ }^{54}$. Inne są także instrumenty, których używają zwycięzcy. Izraelitom towarzyszyły bębenki, na których przygrywały kobiety (Wj 15,20). Bębny były typowymi instrumentami towarzyszącymi zwycięstwu militarnemu. Ich donośny dźwięk i rytm, jaki nadawały, sprzyjały wykonaniu radosnego tańca. W Apokalipsie obecne są instrumenty strunowe, które były instrumentami typowymi dla liturgii świątynnej, a także muzyki dworskiej. Nad morzem w Wj 15 zwycięzcy tańczyli. Tutaj mowa jest

Por. L. Ryken, J.C. Wilhoit, T. Longman III, Słownik symboliki biblijnej, s. 241.

Por. A. Jankowski, Apokalipsa Świętego Jana, s. 171.

Por. L. Ryken, J.C. Wilhoit, T. Longman III, Słownik symboliki biblijnej, s. 241. 
o „stojących”, co nadaje wizji pewnej powagi i spokoju, oraz przemawia za jej liturgicznym charakterem.

Fragment ten stanowi teologiczną podstawę dla śpiewu liturgicznego. Dlaczego śpiewać? Gdyż śpiew jest przekroczeniem zwykłej mowy ${ }^{55}$. Słowa Apokalipsy ukazują także nowy wymiar śpiewania Bogu. Nie jest ono powodowane samą tylko wdzięcznością i radością z wybawienia, ale wskazuje na relację między Bogiem i ludźmi; wynika z miłości, będącej poddaniem ludzkiego serca znów pod Boże panowanie ${ }^{56}$.

Jak to zostało już przedstawione przy okazji omawiania struktury tekstu, treść pieśni zbudowana jest koncentrycznie wokół centralnej sentencji „Kto nie lękałby się.... W pierwszej kolejności wypada omówić części C i C. Następnie przedstawiona jest egzegeza części D.

Łatwo zauważyć charakterystyczne cechy poezji hebrajskiej, tj. występujące tu paralelizmy członów. Część C zawiera paralelizm synonimiczny, w którym trzeci i czwarty wers pieśni, zawierają powtórzenie myśli z wiersza pierwszego i drugiego. Część C’ natomiast zawiera paralelizm klimaktyczny, gdzie poszczególne wersy zawierają powtórzenie i rozwinięcie myśli z wersu poprzedzającego, aby osiągnąć kulminację w ostatnim wersie. Obydwie części zostały powiązane, gdyż stanowią niejako jedność treściową. Obydwie dotyczą dzieł Boga i Jego sprawiedliwości ${ }^{57}$.

Część D jest pytaniem retorycznym. W omawianej strukturze zajmuje on miejsce centralne. Lęk, o którym mowa, jest raczej pełną szacunku, miłości i czci bojaźnią niż pospolitym strachem ${ }^{58}$. Imię Boga jest tu przedstawione jako jedyne godne uwielbienia. Można zauważyć pewną przeciwstawność w stosunku do imienia Bestii, która próbuje dla siebie zagarnąć cześć należną tylko Bogu $^{59}$. Próbując zinterpretować całość tekstu poprzez to zdanie, można wyciągnąć wniosek, że zwycięzcą jest ten, kto nie oddał czci imieniu Bestii, ani jej obrazowi, ani nie wziął na rękę liczby jej imienia, a jego harfa nie posłużyła kultowi fałszywych bogów. Pomimo więc, że sama pieśń nie mówi nic o zwycięstwie, jest pieśnią zwycięstwa, gdyż jest śpiewana na cześć Boga ${ }^{60}$, któremu znów zostanie wszystko poddane. Tylko więc muzyka na cześć Pana brzmi w wizji apokaliptycznej, gdyż wszystkie inne zamilkły (Ap 14,3; 18,22).

\footnotetext{
55 Por. J. Ratzinger, Duch liturgii, s. 126.

56 Por. ibidem, s. 127-128.

57 Por. A. Jankowski, Apokalipsa Świętego Jana, s. 232.

58 Por. H. Balz, фоß'́́, $\alpha$ L, w: Exegetical Dictionary, t. 3, s. 429-432.

59 Por. L. Hartman, o’vo $\mu \alpha$, w: Exegetical Dictionary, t. 2, s. 519-522.

60 Por. A.Y. Collins, Apokalipsa św. Jana, w: Katolicki komentarz biblijny, s. 1563.
} 


\section{Konkluzja}

Ap 15,2-4 ukazuje nierozłączność muzyki od kultu Bożego i historii zbawienia. Zwycięzcy stoją nad brzegiem statycznego morza niewzruszeni, bo już nic im nie zagraża. Śpiewają i grają wyrażając swoje uwielbienie i wdzięczność wobec Boga i Jego dzieła zbawienia. W scenie można wyczuć pewien aspekt wieczności. To uwielbienie, śpiew, muzyka mają już nigdy nie ustać, w przeciwieństwie do muzyki wykorzystywanej w celach bałwochwalczych. To zwycięstwo apokaliptyczne dokonuje się teraz, w życiu każdego człowieka, który według wizji nie oddał czci Bestii, ani jej obrazowi, ani nie przyjął jej znaku na rękę ${ }^{61}$. Równocześnie jest to ostateczne uwielbienie Ojca, któremu wszystko znów zostało poddane ${ }^{62}$. Ważna nauka płynie ze słów pieśni: „Kto nie lękałby się, Panie, i nie wielbił imienia Twojego". W tym kontekście niemożliwością jest, żeby ktoś nie oddał chwały Bogu i ostatecznie wszystko Jemu się podporządkuje i uwielbi Go (Ap 15,4).

Widoczna jest analogia do wydarzeń z Wj 15 . Obydwie sceny spinają historię zbawienia jakby klamrą. Trudno nie zauważyć także odniesienia do opisu stworzenia świata. Świat u swego początku był bezmiarem wód - chaosem. Bóg tworzył świat porządkując go, wyznaczając granicę morzu. Po raz kolejny ta granica została wyznaczona nad morzem w Wj 15, aby lud mógł bezpiecznie przejść. Zwycięstwo nad wodami jest zwycięstwem nad złem i chaosem. Szklane morze jest ostatecznym uporządkowaniem świata. Muzyka towarzyszy zwycięzcom, wyrażając całkowitą harmonię Stwórcy i stworzenia. Z definicji przecież jest ona porządkiem.

\section{Bibliografia}

\section{Literatura źródłowa}

Biblia w przekładzie ks. Jakuba Wujka z 1599 r., Warszawa 2000.

Biblia warszawsko-praska, Warszawa 1997.

Novum Testamentum Graece, red Aland B. i K., Karavidopoulos J., Martini C.M., Stuttgart 2006.

Pismo Święte Starego i Nowego Testamentu, Edycja Świętego Pawła, Częstochowa 2008.

Por. M. Szamot, Apokalipsa czytana dzisiaj, s. 188-189.

62

Por. T. Jelonek, Biblia jako fenomen kulturowy, s. 466-478. 
Pismo Święte Starego i Nowego Testamentu, Wydawnictwo Pallottinum (Biblia Tysiąclecia), Poznań 2007.

\section{Literatura przedmiotu}

Balz H., Cháragma, w: Exegetical Dictionary of The New Testament, red. H. Balz, G. Schneider, t. 3, Grand Rapids 1990, s. 455-456.

Balz H., Phobéomai, w: Exegetical Dictionary of The New Testament, red. H. Balz, G. Schneider, t. 3, Grand Rapids 1990, s. 429-432.

Bauckham R., Revalation, w: The Oxford Bible Commentary, red. J. Barton, J. Muddiman, Oxford 2001, s. 1287-1306.

Chomiński J., Wilkowska-Chomińska K., Historia muzyki, Kraków 1989, t. 1.

Collins A.Y., Apokalipsa św. Jana, w: Katolicki komentarz biblijny, red. R.E. Brown, J.A. Fitzmyer, R.E. Murphy, Warszawa 2001, s. 1542-1572.

Ehrman B.D., Przeinaczanie Jezusa. Kto i dlaczego zmieniał Biblię, tłum. M. Chowaniec, Warszawa 2009.

Hartman L., Ónoma, w: Exegetical Dictionary of The New Testament, red. H. Balz, G. Schneider, t. 2, Grand Rapids 1990, s. 519-522.

Herrgott G., Liczba, w: Praktyczny słownik biblijny. Opracowanie zbiorowe katolickich i protestanckich teologów, red. A. Grabner-Haider, tłum. T. Mieszkowski, P. Pachciarek, Warszawa 1994, kol. 651.

Jankowski A., Apokalipsa Świętego Jana: wstęp, przekład z oryginału, komentarz, Poznań 1959.

Kratz R., Thálassa, w: Exegetical Dictionary of The New Testament, red. H. Balz, G. Schneider, t. 2, Grand Rapids 1990, s. 127-128.

Kuhli H., Eikôn, w: Exegetical Dictionary of The New Testament, red. H. Balz, G. Schneider, t. 1, Grand Rapids 1990, s. 388-391.

Kunzler M., Liturgia Kościoła, Poznań 1999.

Michels U., Atlas muzyki, tłum. P. Maculewicz, Warszawa 2002, t. 1.

Montagu J., Instrumenty muzyczne biblii, Kraków 2006.

Niditch S., Judges w: The Oxford Bible Commentary, red. J. Barton, J. Muddiman, Oxford 2001, s. 176-191.

O’Connor M., Księga Sędziów, w: Katolicki komentarz biblijny, red. R.E. Brown, J.A. Fitzmyer, R.E. Murphy, Warszawa 2001 s. 213-234.

Pauritsch K., Obraz, w: Praktyczny słownik biblijny. Opracowanie zbiorowe katolickich i protestanckich teologów, red. A. Grabner-Haider, tłum. T. Mieszkowski, P. Pachciarek, Warszawa 1994, kol. 860.

Ratzinger J., Duch liturgii, tłum. E. Pieciul, Poznań 2002.

Ratzinger J., Nowa pieśn dla Pana, tłum. J. Zychowicz, Kraków 2005.

Ryken L., Willhoit J.C., Longman III T., Słownik symboliki biblijnej. Obrazy, symbole, motywy, metafory, figury stylistyczne i gatunki literackie w Piśmie Świętym, tłum. Z. Kościuk, Warszawa 2003.

Scholes P.A., The Oxford Companion to Music, London 1977. 
Strobel A., Therion, w: Exegetical Dictionary of The New Testament, red. H. Balz, G. Schneider, t. 2, Grand Rapids 1990, s. 148-149.

Szamot M., Apokalipsa czytana dzisiaj, Kraków 2000.

Wojciechowski M., Apokalipsa Świętego Jana: objawienie, a nie tajemnica. Wstęp, przekład $z$ oryginału, komentarz, Częstochowa 2012.

\section{Pomoce naukowe}

Popowski R., Wielki słownik grecko-polski Nowego Testamentu, Warszawa 1995. 